\title{
Study of Phenology of Chrysanthemum segetum L. and Its Impact on Crop Productivity in Cheliya District, Ethiopia
}

\author{
Shashitu Bedada Ejeta \\ EIAR, Plant Protection Research Centre. P. O. Box 37. Ambo. Ethiopia
}

\begin{abstract}
Studies on distribution, impact and phenology of Chrysanthemum segetum was carried out in Cheliya district. The aim was to study the distribution, impact and phenology of C. segetum. Assessment was done at regular interval of $5 \mathrm{~km}$ along gravile and main roadsides. Phenology of the weed was investigated under the natural conditions through regular visit. C. segetum was distributed in specific surveyed locations having different altitudinal ranges from 1993-2820m in study area. It was observed to infest crop land and grazing lands, but its infestation was found most serious at crop land than grazing lands. Scale of infestation of the weed varied among different locations depending up on time of its introduction in to the area. Animal dung, flood, crop seed, birds and farm machinery is found to be the major dispersal agents. Most of the farmers in the surveyed areas have recognized C. segtum invasion cause significant reduce in crop yield. C. segtum was ranked as first based on its negative impact on crop production and productivity. Hand weeding is the most common practice to manage $\mathrm{C}$. segetum infestation in the study areas. The weed started to germinate at early May to late July even extended to August; flowering in early August to mid-September and the seeds fully ripened in September to December and even it extended to January at the study area. C. segetum produce high number of branch per plant (75.50) and averages of seeds per plant $(11,551)$. The present investigation indicated that $\mathrm{C}$. segetum significantly reduce crop productivity. Phenology of $\mathrm{C}$.segetum was studied. Therefore, there is a need to develop scientifically proven control measure and contain the further spread of the weed to non-infested areas.
\end{abstract}

Keywords: Chrysanthemum segetum, Phenology, Relative frequency, Percentage frequency Distribution, Impact, Infestation

DOI: $10.7176 / \mathrm{JBAH} / 9-2-04$

\section{Introduction}

Chrysanthemum segetum L. $(2 \mathrm{n}=2 \mathrm{x}=18)$ is a member of compositae; it is widely distributed in the Mediterranean, western Africa, and Asia (1). C. segetum is a Mediterranean species with sub Atlantic features $(13,16)$. It is fairly common in England, the Netherlands, in the German and French lowlands, and it is rare in central Europe, North Africa and on the Caspian Sea coasts. The northern range reaches Ireland, Scotland, Sweden, southern Norway and Finland. This rare species have been recorded in the Northern part Iberian Peninsula, on the Balkans, in Southern Ukraine and also in single localities in western Syria (8). In Ethiopia its wide infestation has been reported in highlands of northern Ethiopia (2).

C. segetum is commonly cultivated as a medicinal (insecticidal and antifungal activity) and vegetable plant in South of China $(11,12)$. In Crete and Greece, the leaves and the tender shoots of a variety called neromantilida are eaten raw in salads or browned in hot olive oil by the locals (9). However, the $C$. segetum appears to have been a serious weed during the 13th century in Scotland (4). Moreover, it was observed very recently but invading crop lands at alarming rate in Cheliya district of West Shewa Zone of Ethiopia. Farmers and Agricultural development agents of the area mentioned their great concern that the weed is expanding fast and found difficult to control using existing farm practices including 2, 4-D herbicide application. C. segetum can be a weed of economic importance in spring-sown wheat and barley, particularly in light loam or sandy soils (5). C. segetum is a weed in pastures and arable land (both root crops and cereals, especially barley), and infestations frequently form fairly dense stands (7). C. segetum has been observed being grazed by cattle and horses. Seeds may be dispersed through dung of cattle and horses, or in bird droppings and as a contaminant with crop seeds (7).

Invasive plants has been of recent concern as they represent a considerable environmental challenge, causing negative impacts on ecological communities in their introduced ranges, disturbs the structure and composition of the native vegetation on a large extent and as result crate pressure on the food chain and web of the ecosystem $(10,14)$. In agricultural habitats which are particularly susceptible to alien plants can assume the status of harmful weeds. The control of new invasion of weed is more successful at earlier, so that early recognition of potential invaders based on information on their climatic and environmental preferences as well as their status outside their current range is important (3). In the present investigation, C. segetum was found to be the most noxious weed which significantly reduces crop productivity. Phenology of $C$. segetum was studied. Therefore, this study was undertaken to investigate the distribution and impact of C. Segetum and Phenology of the weed. 


\section{Materials and Methods}

Description of the study area

The study site was in West Shewa Zone of Oromiya regional state, Cheliya District. The district is located around $200 \mathrm{~km}$ away from Addis Ababa. This area is thought to be the first introduction site of this particular weed. Gedo is the major town of the Cheliya District, is located at 9.0834394 N latitudes and $37.383355 \mathrm{E}$ longitudes with an altitude of $2849 \mathrm{~m}$ above sea level.

Assessment on distribution and impacts of C. segetum

A survey was conducted in 2015/16 during main cropping season. A different location of Cheliya district was examined to assess distribution and infestation level of $C$. Segetum. The major crops growing in the surveyed area are Teff, Barley, Wheat, Field pea, lien seed, and Niger seed. Assessment was conducted in different habitats: cultivated land, road side and grass lands to draw exhaustive inventory of $C$. Segetum infestation. Assessment was done at regular interval of $5 \mathrm{~km}$ along gravile and main roadsides. The infestation of $C$. Segetum was estimated by counting the number of plants per $\mathrm{m}^{2}$ following the methods used by Taye et al. (1998) with some modifications. Four counts were taken per location and then converted in to scale of $C$. Segetum infestation: No infestation $=$ no $C$. Segetum observed in the field, Very low infestation $=1-10$ C. Segetum infestation per $\mathrm{m}^{2}$, Low infestation $=11-20$ C.Segetum infestation per $\mathrm{m}^{2}$, Medium infestation $=21-30$ C. Segetum infestation per $\mathrm{m}^{2}$, High infestation $=31-40 C$. Segetum infestation per $\mathrm{m}^{2}$, Very high infestation $=$ more than $41 C$. Segetum infestation per $\mathrm{m}^{2}$. The altitude, latitude, longitude and other data related to the weed plant was recorded using GPS.

Semi structured questionnaires were developed on farmer's perception, on place and year of first observation, dispersal agents, land use type invaded by $C$. segtum, negative impacts, traditional management method attempted by farmers. A total of 60 local people (farmers) and development agents at the study area were interviewed considered for the questionnaire.

\section{Study on phenology of $C$. segtum}

Phenology of the weed was investigated under the natural conditions at the study area in 2015/16 during main cropping season. Undisturbed pilot sites with $10 \mathrm{~m} \mathrm{X} 10 \mathrm{~m}$ at three different locations were selected for regular visit and recording phenology of the weed over a growth season. Data on time of germination, flowering, seed setting and maturity were recorded through regular visiting. Number of branches per stem, C. segetum height, root length, number of flower heads per plant, number of seeds per flower, and number of seeds per plant were collected from ten randomly selected $C$. segetum weeds. The means of each collected data were calculated and used.

\section{Method of data analysis}

Data on farmer's perception were analyzed and summarized using frequency, relative frequency and percentage frequency which is described as fallow.

The relative frequency was calculated by dividing the frequency by the number of observations.

Thus: Relative frequency $=\underline{\text { frequency }}$

Number of observations

The percentage frequency is found by multiplying each relative frequency value by 100

Thus: Percentage frequency=Relative frequency X100

Data on weed phenology such as: number of branches per stem, weed plant height, root length, number of flower heads per plant, number of seeds per flower, number of seeds per plant were calculated by using mean of ten samples.

$$
\text { Mean }=\underline{\mathrm{N}_{1}} \frac{+\mathrm{N}_{2}}{\mathrm{~N}_{\mathrm{n}}}+\ldots \ldots \ldots \ldots+\mathrm{N}_{\underline{n}}
$$

Where, $\mathrm{N} 1=$ number of sample1, $\mathrm{N}_{2}$ number of sample $2 \ldots \ldots \ldots, \mathrm{N}_{\mathrm{n}}=$ number of sample $\mathrm{n}$

\section{Results and Discussion}

\section{Distribution and Spread of $C$. segetum infestation in Cheliya District}

Interview to farmers indicated that C. segetum was introduced in to the area intentionally in 1928s during Ethio Italy war for use as horse feed by Italian. Other said it was introduced during Durg regime imported from other country as a contaminant of grain food aid during famine and distributed with the grain. Know it is spreading to different location of the district at an alarming rate. However it has now emerged as one of the most aggressive weeds of crop land and is considered as a noxious weed because of its prolific seed production, fast spreading ability, strong competitiveness with crop, and its high number of branches which cannot be easily up rooted and cutting aggravate its infestation.

Survey of $C$. segetum in Cheliya district showed that it is highly distributed in specific surveyed locations 
having different altitudinal ranges from 1993-2820 $\mathrm{m}$ in study area. It was observed to infest crop land and grazing lands but its infestation was found most serious at crop land than grazing lands.

Scale of infestation of $C$. segetum varied among different locations depending up on time of its introduction and spread in to the area. Very high infestation was recorded at Jara, Amart, Wagdi and Bayimo location, whereas high infestation was recorded at, Hula- qumbala, medium infestation was recorded Goda-waliyi and Hole, Low infestation was recorded at Chobi and Galone, very low infestation was recorded at Daraba, Tuluhantuta, Nya and Bere (Table 1).

Table 1. Infestation of C. segetum in different location of Cheliya District (2015/16)

\begin{tabular}{|c|c|c|c|c|c|c|}
\hline Kebele & Location & Altitude & $\begin{array}{l}\text { GPS position } \\
\text { Lat./Long. }\end{array}$ & $\begin{array}{l}\text { Infested } \\
\text { habitat }\end{array}$ & $\begin{array}{l}\text { Average } \\
\text { weeds per m2 }\end{array}$ & $\begin{array}{l}\text { Scale of } \\
\text { infestation }\end{array}$ \\
\hline $\begin{array}{l}\text { Waliye } \\
\text { Chelelaki }\end{array}$ & $\begin{array}{l}\text { Goda } \\
\text { waliyi }\end{array}$ & 2434 & 09023.87’N,037443.02’E & Crop land & 30 & Medium \\
\hline Secondo & Jaraa & 2427 & 09012.90’N,037261.66’E & Crop land & 42 & Very high \\
\hline $\begin{array}{l}\text { Chobi tulu } \\
\text { chori }\end{array}$ & Chobi & 2498 & 09031.22’N,037449.08'E & Crop land & 11 & Low \\
\hline $\begin{array}{l}\text { Chobi tullu } \\
\text { chori }\end{array}$ & Hole & 2557 & 09022.00’N,037271.58'E & Crop land & 29 & Medium \\
\hline $\begin{array}{l}\text { Chobi tulu } \\
\text { chori }\end{array}$ & Amart & 1993 & 09010.79’N,037404.32’E & Crop land & 103 & Very high \\
\hline $\begin{array}{l}\text { Rafiso } \\
\text { halanga }\end{array}$ & $\begin{array}{l}\text { Hula } \\
\text { qumbala }\end{array}$ & 2686 & 09025.47’N,037263.10’E & Crop land & 35 & High \\
\hline $\begin{array}{l}\text { Rafiso } \\
\text { halanga }\end{array}$ & Daraba & 2643 & 09056.24’N,037447.59’E & Grass land & 2 & Very low \\
\hline $\begin{array}{l}\text { Halee Hula } \\
\text { dhabi }\end{array}$ & $\begin{array}{l}\text { Tulu } \\
\text { hantuta }\end{array}$ & 2748 & 09067.53’N,037402.75'E & Grass land & 4 & Very low \\
\hline $\begin{array}{l}\text { Halelu oda } \\
\text { guta }\end{array}$ & Nyaa & 2820 & 09101.47’N,037437.99'E & Grass land & 1 & Very low \\
\hline $\begin{array}{l}\text { Wagidi } \\
\text { kortu }\end{array}$ & Wagidi & 2653 & 08595.27’N,037272.27’'E & Crop land & 70 & Very high \\
\hline $\begin{array}{l}\text { Wagidi } \\
\text { kortu }\end{array}$ & Bayimo & 2583 & 08585.94’N,037551.40’E & Crop land & 52 & Very high \\
\hline Tulu nacha & Galone & 2323 & 08753.44’N037272.60’E & Crop land & 14 & Low \\
\hline Tulu nacha & Beree & 2404 & 08574.55’N,037274.12’E & Gass land & 3 & Very low \\
\hline
\end{tabular}

Key: *Scale of $C$. segetum infestation: Very low infestation $=1-10$ C. segetum infestation per $\mathrm{m}^{2}$, Low infestation $=11-20$ C. segetum infestation per $\mathrm{m}^{2}$, Medium infestation $=21-30 \mathrm{C}$. segetum infestation per $\mathrm{m}^{2}$, High infestation $=31-40$ C. segetum infestation per $\mathrm{m}^{2}$, Very high infestation $=$ more than 41 C. segetum infestation per $\mathrm{m}^{2}$

\section{Community perception on Dispersal agents, impact and traditional management of C. segtum Dispersal agents:}

Responses from the community indicated that C. segtum is spreading by animal dung, flood, crop seed, birds and farm machinery this indicating that the communities have awareness on the mechanism of spread (Table 2). Respondents of the study area indicated that the seeds can pass through the digestive system of horse without loss of viability and also seed has been found as a contaminant of cereal seeds. Literature also supported that $C$. seedling have been raised from the dropping of various birds (7). Knowing the mechanism of spread is helpful for controlling further spread. In the surveyed area, infestation of $C$. segtum varied from location to location depending up on time of its introduction and spread in to the area.

Table 2. Farmers perception on dispersal agent of C. segetum $(n=60)$

\begin{tabular}{llll}
\hline Dispersal agent & Frequency & Relative frequency & Percentage frequency \\
\hline Wind & 17 & 0.283 & 28 \\
Birds & 4 & 0.067 & 6.7 \\
Animal dung & 31 & 0.517 & 51.7 \\
Flood & 20 & 0.333 & 33.3 \\
By crop seed & 25 & 0.417 & 41.7 \\
Farm machineries & 4 & 0.667 & 6.7 \\
\hline
\end{tabular}

Land use type invaded by $C$. segtum:

According to the respondent the density of $C$. segtum was observed to be high in cultivated land than grazing land (Table 3). This could be due to the fact that the seed dissemination was facilitated through crop seed and 
farm machinery as well as it prefers cultivated lands than grazing land.

Table 3. Land use type invaded by C. segtum $(\mathrm{n}=60)$

\begin{tabular}{llll}
\hline Land use type & Frequency & Relative frequency & Percentage frequency \\
\hline Cultivated land & 57 & 0.95 & 95 \\
Grazing land & 3 & 0.05 & 5
\end{tabular}

\section{Negative impacts:}

The entire of the respondent mentioned that $C$. segetum invasion reduce crop yield. About $47 \%$ of the respondent's farmers perceive $C$. segetum invasion increasing cost of production. Reduction in crop quality was also perceived by $17 \%$ of the farmers. Harvesting problem, reduction of soil fertility and consumption of farmer's time were stated by $12 \%$ of the farmers respectively (Table 4 ). This indicated that most of the farmers in the surveyed areas have recognized, C. segetum invasion reduce crop yields. However the perception of farmers on the impact of the weed on harvesting, soil fertility and farmers were rear. But farmers in the study area mention that due to the strength of weed injure farmers hand due to difficulty of uprooting.

Table 4. Negative Impacts of C. segetum $(\mathrm{n}=60)$

\begin{tabular}{llll}
\hline Negative impacts & Frequency & Relative frequency & Percentage frequency \\
\hline Yield reduction & 60 & 1.00 & 100 \\
Increase cost of production & 28 & 0.47 & 47 \\
Reduce crop quality & 10 & 0.17 & 17 \\
Harvesting problem & 7 & 0.12 & 12 \\
Reduced soil fertilities/land degradation & 7 & 0.12 & 12 \\
Consume farmers time & 7 & 0.12 & 12
\end{tabular}

According to farmers perception $C$. segtum was categorized as the most important weed species having negative impact on crop production followed by Snowdina polstachiya, Raphanus rafanistrum, and Gizotia scabra respectively on the study areas (Table 5). This result indicated that $C$. segtum was the most serious weed of crop land which causes significant yield reduction in the study area.

Table 5. Ranks of weed species based on its negative impact on crop production $(n=60)$

\begin{tabular}{llll}
\hline Weed type mentioned & Frequency & Relative frequency & Percentage frequency \\
\hline C. segtum & 45 & 0.75 & 75 \\
Snowdina polstachiya & 7 & 0.12 & 12 \\
Raphanus rafanistrum & 5 & 0.83 & 8 \\
Gizotia scabra & 3 & 0.05 & 5
\end{tabular}

Traditional management method attempted by farmers:

According to the respondents the most frequently applied control method was hand pulling. However, other management practice like crop rotation; fallowing, dry season plowing, sowing clean seed and burning were rarely practiced (Table 6). Therefore, the existing farmer's sole management option is hand weeding, though it has its own limitations. The weed cannot be easily up rooted especially during rainy season due to its strength of the stem and found difficult to control using existing farm practices including 2,4- D herbicide. Therefore, there is a need to develop appropriate measure to contain the further spread of this aggressive weed in non-infested area and looking for scientifically proven weed management technologies.

Table 6. Management measure applied by farmers

\begin{tabular}{llll}
\hline Control technique & Frequency & Relative frequency & Percentage frequency \\
\hline Repeated hand pulling & 53 & 0.88 & 88 \\
Dry season ploughing & 1 & 0.02 & 2 \\
Crop rotation & 2 & 0.03 & 3 \\
Fallowing & 2 & 0.03 & 3 \\
Sowing clean seed & 1 & 0.02 & 2 \\
Burning & 1 & 0.02 & 2
\end{tabular}

\section{Phenology of $C$. segtum}

Germination of $C$. segtum started after first ploughing at early May to late July even extended to August. Flowering started appearing in early August to mid-September. The seeds fully ripened in September to December and even it extended to January at Cheliya condition.

The mean of $C$. segtum height, root length, number of branches, number of flower head and number of seeds per flower heads counted in three different locations. As indicated in the table (7) the highest mean height $(78.7 \mathrm{~cm})$ and mean number of branches (76) were recorded at Tulu wagdi. Research done in North America indicated that the weed can grow up to $80 \mathrm{~cm}(5)$. However the highest mean root length $(16.5 \mathrm{~cm})$ and number of seeds per flower heads (243) were recorded at Wagidi kortu location. This indicated that C. segetum height, 
root length, number of branches, flower head per plant and number of seeds vary from location to location.

Study result shows that averages of 11,502 C. segtum seeds per plant have been recorded. This indicated that $C$. segtum produce high number of branches and seeds per plants. Therefore, managing C. segtum weed at early stage before seed setting and clean seed sowing is very important to reduce further spread.

Table 7. Mean height, root length stem branches, number of flower per heads and number of seeds per flower head of C. segtum

\begin{tabular}{|c|c|c|c|c|c|c|}
\hline Location & $\begin{array}{l}\text { Height } \\
(\mathrm{Cm})\end{array}$ & $\begin{array}{l}\text { Root } \\
\text { length } \\
(\mathrm{Cm})\end{array}$ & $\begin{array}{l}\text { Number } \\
\text { branches/plant }\end{array}$ & $\begin{array}{l}\text { Number } \\
\text { flower } \\
\text { heads/plant }\end{array}$ & $\begin{array}{l}\text { Number of } \\
\text { seeds } \\
\text { per flower } \\
\text { heads }\end{array}$ & $\begin{array}{l}\text { Number of Seed } \\
\text { Per plant }\end{array}$ \\
\hline $\begin{array}{l}\text { Wagidi } \\
\text { kortu }\end{array}$ & 73.30 & 16.50 & 17.50 & 25.90 & 243.2 & 6298 \\
\hline Tulu wagidi & 78.70 & 9.06 & 75.50 & 102.40 & 230 & 23552 \\
\hline $\begin{array}{l}\text { Chobi tulu } \\
\text { chori }\end{array}$ & 52.70 & 13.10 & 32.80 & 33.80 & 165 & 5577 \\
\hline Mean & 68.2 & 12.88 & 41.93 & 54.03 & 212.73 & 11551 \\
\hline
\end{tabular}

\section{Conclusion}

The result of the present study provide a base line information of the invasion and spread of C. segetum weeds on crop land and grazing lands of Cheliya district. C. segetum was found most serious weed at crop land than grazing lands. The weed produces large number of branches and seeds per plant. Managing C. segetum weed at early stage before seed setting and sowing clean seed is very important to reduce further spread. Its invasion is expanding at fast rate and found difficult to control using existing farmer's practices including 2, 4-D herbicide application. The present investigation indicated that $C$. segetum significantly reduce crop productivity. Therefore, there is a need to develop scientifically proven control measure and contain the further spread of the weed to non-infested areas.

\section{Acknowledgments}

We gratefully acknowledge Ethiopian Institute of Agricultural Research Ambo Plant Protection Research Center for providing the facilities required for the study. We would also like to thank Ambo Plant Protection Weed Science team for his unreserved technical support and for his assistance during the field work.

\section{References}

1. Alvarez-Castellanos PP, Bishop CD, Pascual- Villalobos MJ(2001) Antifungal activity of the essential Alvarez-Castellanos PP, Bishop CD, Pascual-Villalobos MJ (2001) Antifungal activity of the essential oil of flowerheads of garland chrysanthemum (Chrysanthemum coronarium) against agricultural pathogens. Phytochemistry 57:99-102.

2. Asres, B. D. T, (2011) Diversity and Integrated Management of Weeds in Highland Wheat of Northern Ethiopia. Plant Protection Quarterly Volume 26 Issue.

3. Chytry,M., Pysek, P., Wild, J., Pino, J., Maskell, L.C. and Vila, M (2009) European Map of alien plant invasions based on the quantitative assessment across habitats. Diversity and Distributions 15: 98-107

4. Dalrymple, Sir David (1776). Annals of Scotland. Pub. J. Murray. London. P. 338 -339

5. Flora of North America, Glebionis segetum (Linnaeus) Fourreau (1869) Corn marigold

6. Frost C. (1982) Effects of herbicides alone or in mixtures on dicotyledonous weeds in Wheat and Barley Irish Journal of Agricultural Research, 21(2/3): 211-226. Available at http://www.jstor.org/pss/25556034 (verified 6 May 2010).

7. Howarth SE and Williams JT. (1972) Chrysanthemum segetum L. Journal of Ecology 60(2): 573-584. Available at http://www.jstor.org/pss/2258362 (verified 6 May 201

8. Hulten E., Fries M (1989) Atlas of north Europaean vascular plants. North of the tropic of Cancer, 3:11371063. Koeltz Scientific Books, Konigstein.

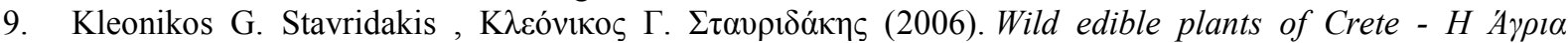

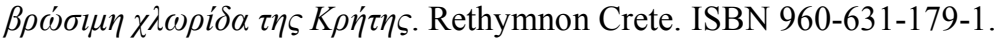

10. Mack, R.N., Simberloff, D. Lonsdale, W.M Evans H., Clout, M. and Bazzaz, F.a (2000) Biotic invasions: Causes, epidemiology, global consequences, and control ecological applications 10; 689-710.

11. Ochocka RJ, Rajzer D, Kowalski P, Lamparczyk H (1995) Determination of coumarins from Chrysanthenum segetum L. by capillary electrophoresis. J Chromatogr A 709:197-202.

12. Perez MP, Navas-Cortes JA, Pascual-Villalobos MJ, Castillo P (2003) Nematicidal activity of essential oils and organic amendments from Asteraceae against root-knot nematodes. Plant Pathol 52:395-401

13. Perring F.H., Walters S.M (1990) Atlas of the British flora. Ss. 441. Bot. Society of the British. 
14. Pimentel D, Lach L, Zuniga R, Morrison D (2000). Environmental andeconomic costs of non indigenous species in the United States. Biosci., 50: 53-65.

15. Taye, T and Yohannes, L. 1998. Qualitative and quantitative determination of weeds in teff in west Shewa Zone.Arem 4: 46-60.

16. Zajac A (1979) Pochodzenie archeofitow wystepujacych w Polsce. Rozpr. Hab. UJ 29: 1-113. 